\title{
UJI KANDUNGAN TOTAL POLIFENOL DAN FLAVONOID EKSTRAK ETIL ASETAT KULIT PISANG RAJA (Musa paradisiaca var. sapientum)
}

\author{
Ida Adhayanti*), Tajuddin Abdullah ${ }^{*}$, Rika Romantika*) \\ ${ }^{*}$ Jurusan Farmasi Poltekkes Kemenkes Makassar
}

\begin{abstract}
ABSTRAK
Tanaman pisang adalah salah satu tanaman unggulan di Indonesia, karena besarnya volume produksi nasional dan luas hasil panen. Kulit pisang raja memiliki kadar senyawa fenolik yang jauh lebih tinggi daripada yang terkandung pada daging buahnya. Penelitian ini bertujuan untuk mengetahui kandungan total polifenol dan flavonoid ekstrak etil asetat kulit pisang raja (Musa paradisiaca var. sapientum). Kulit pisang raja diekstraksi dengan metode maserasi menggunakan pelarut etanol 96\%. Kandungan fenolik total ditentukan secara spektrofotometri UV-Vis menggunakan reagen Folin-Ciocalteu yang dinyatakan dalam GAE (Garlic Acid Equivalent) dan kandungan flavonoid total menggunakan reagen $\mathrm{AlCl}_{3}$ dan dinyatakan dalam $\mathrm{QE}$ (Quersetin Equivalent). Larutan tersebut kemudian diukur absorbansinya dengan panjang gelombang $656 \mathrm{~nm}$ untuk polifenol dan 440 untuk flavonoid. Hasil penelitian menunjukkan bahwa kandungan total polifenol 3,50104 \% b/v atau 35,0104 mg GAE/g ekstrak dan kandungan total flavonoid 2,076153 $\% \mathrm{~b} / \mathrm{v}$ atau $20,76153 \mathrm{mg} \mathrm{QE} / \mathrm{g}$ ekstrak.
\end{abstract}

\section{Kata Kunci : Ekstrak Etanol Kulit Pisang Raja, kandungan fenolat total, kandungan flavonoid total, spektrofotometri UV-Vis}

\section{PENDAHULUAN}

Tumbuhan merupakan salah satu sumber obat-obatan yang diperlukan dalam dunia medis. Salah satu tanaman yang dapat dijadikan sebagai bahan pembuatan obatobatan tradisional adalah tanaman pisang. Indonesia merupakan salah satu Negara yang memiliki keanekaragaman pisang sehingga menjadikannya sebagai salah satu Negara pengekspor pisang. Seluruh bagian tanaman pisang dapat dimanfaatkan, mulai dari bonggol, batang, bunga, daun dan buahnya. Kandungan gizi yang terdapat dalam setiap buah pisang matang adalah kalori, protein, lemak, karbohidrat, serat, kalsium, fosfor, besi, vitamin A, vitamin B, vitamin $\mathrm{C}$ dan air. Beberapa penelitian menyebut buah pisang bisa membantu mengatasi depresi, anemia, tekanan darah, sembelit, sakit jantung, gangguan saraf, dan mensuplai energi dalam otak (Sumathy dalam Chabuck dkk., 2013).

Tanaman pisang adalah salah satu tanaman unggulan di Indonesia, karena besarnya volume produksi nasional dan luas hasil panen yang melebihi komoditi lainnya (Deptan, 2005). Data produksi buah Indonesia tahun 2013, menunjukkan bahwa produksi pisang adalah sebesar 5.359.126 ton dan merupakan jumlah produksi buah terbesar dibandingkan dengan buah lainnya (Badan Pusat Statistik Republik Indonesia, 2013). Data tersebut memperlihatkan bahwa tanaman pisang merupakan salah satu tanaman yang melimpah di Indonesia. Namun, tanaman pisang belum memiliki acuan informasi yang lengkap dari segi fitokimia maupun segi farmakologi. Pemanfaatan tanaman pisang dalam bidang industri selama ini masih belum populer. Selain itu, bagian tanaman pisang yang paling sering dimanfaatkan hingga saat ini masih terbatas pada bagian buahnya, sedangkan bagian lain seperti bagian kulit buah, batang, daun, akar, dan pelepah pisang masih dianggap sebagai limbah dan pengolahan lebih lanjut dari bagian tersebut masih sangat sedikit (Pane, 2013).

Kulit pisang juga memiliki banyak manfaat namun belum banyak dimanfaatkan oleh masyarakat. Kulit buah pisang dapat meredakan nyeri pada luka bakar, mengatasi gatal pada kult, mengobati kutil, mempercepat penyembuhan luka yang sudah mulai kering dan menyuburkan tanah (sebagai pupuk). Kulit pisang bahkan digunakan untuk memurnikan air dan menyaring logam berat terutama timbal $(\mathrm{Pb})$ dan tembaga (Cu) (Sopyan, 2012). 
Pada penelitian ini dipilih kulit pisang raja karena kulit pisang memiliki kadar senyawa fenolik yang jauh lebih tinggi daripada yang terkandung pada daging buahnya (Humairani, 2007). Proses ekstraksi dilakukan dengan metode maserasi menggunakan pelarut etanol $96 \%$. Pemilihan metode ini didasarkan pada penarikan senyawa kimia yang terdapat dalam simplisia yang tidak tahan pemanasan sehingga digunakan metode maserasi tujuannya agar senyawa yang tidak tahan pemanasan tidak rusak serta peralatan yang digunakan sederhana dan mudah untuk diusahakan (Depkes, 1986).

\section{Rumusan masalah}

Berdasarkan latar belakang diatas, maka rumusan masalah dalam penelitian ini adalah berapa kandungan total polifenol dan flavonoid ekstrak etil asetat kulit pisang raja (Musa paradisiaca var. sapientum)?

\section{Tujuan penelitian}

Adapun tujuan dari penelitian ini adalah untuk mengetahui kandungan total polifenol dan flavonoid ekstrak etil asetat kulit pisang raja (Musa paradisiaca var. sapientum)

\section{Manfaat penelitian}

Adapun manfaat dari penelitian ini adalah dapat menambah wawasan tentang kandungan total polifenol dan flavonoid ekstrak etil asetat kulit pisang raja (Musa paradisiaca var. sapientum)

\section{METODE DAN BAHAN \\ Jenis penelitian}

Penelitian ini merupakan penelitian observasi laboratorium yang bertujuan untuk mengetahui kandungan total polifenol dan flavonoid ekstrak etil asetat kulit pisang raja ( Musa paradisiaca var. sapientum ).

\section{Waktu dan tempat penelitian}

Penelitian ini telah dilakukan pada tanggal 21 maret - 15 juni 2017 yang bertempat di Laboratorium Kimia Jurusan Farmasi Poltekkes Kemenkes Makassar pada bulan April 2017.

\section{Alat dan bahan}

Alat-alat yang digunakan adalah batang pengaduk, gelas ukur, labu ukur, buret, statif, gelas kimia, pipet tetes, labu Erlenmeyer, sendok tanduk, timbangan analitik, corong gelas, pipet volum, spektrofotometri UV-Vis, vial, aluminium foil, bejana maserasi. Sedangkan bahan yang digunakan adalah kulit pisang raja ( $\mathrm{Musa}$ paradisiaca var. sapientum ) dan pelarut berupa etanol, etil asetat

\section{Pengambilan dan penyiapan sampel}

Sampel yang digunakan adalah kulit pisang raja ( Musa paradisiaca var. sapientum ). Kulit tersebut dipisahkan dari buahnya kemudian dibersihkan dari kotoran yang menempel dengan air yang mengalir sampai benar-benar bersih. Kemudian kulit buah pisang raja dipotong kecil-kecil dan dikeringkan dengan caradi oven pada suhu sekitar $50^{\circ} \mathrm{c}$ sampai benar-benar kering. Setelah kering, dilakukan sortasi kering, kemudian simplisia yang didapat kemudian ditimbang untuk proses ekstraksi selanjutnya.

\section{Prosedur kerja}

1. Pembuatan ekstrak Sejumlah 250 g simplisia Pisang raja ( Musa paradisiaca sapientum ) dimasukkan kedalam bejana maserasi kemudian ditambahkan pelarut etanol sampai seluruh sampel terendam sempurna. Simplisia diaduk rata, kemudian bejana maserasi ditutup rapat. Proses maserasi dilakukan dengan beberapa kali pengadukan dan disimpan ditempat gelap pada suhu kamar. Maserat yang dihasilkan kemudian disaring dengan menggunakan kapas. Kemudian filtrate diuapkan hingga diperoleh ekstrak kental.

2. Fraksinasi ekstrak

a. Ekstrak etil asetat

1. Ekstrak etanol sebagian dimasukkan kedalam gelas piala kemudian ditambahkan $20 \mathrm{ml}$ air suling dan $10 \mathrm{ml}$ larutan etil asetat, lalu diaduk

2. Dimasukkan ke dalam corong pisah, didiamkan hingga terjadi pemisahan antara air dan etil asetat.

3. Kemudian dikeluarkan air, dimasukkan ke dalam gelas piala dan etil asetat 
dimasukkan ke dalam vial sebagai ekstrak etil asetat.

\section{Uji kualitatif}

\section{Uji alkaloid}

Ekstrak ditimbang 0,5 gram, dimasukkan kedalam tabung reaksi, dilarutkan dengan $1 \mathrm{ml} \mathrm{HCl} 2 \mathrm{~N}$ dan $9 \mathrm{ml}$ air, kemudian dibagi menjadi 3 bagian, hasilnya positif mengandung alkaloid jika ditambahkan pereaksi mayer akan membentuk endapan putih (putih kekuningan) dan jika ditambahkan pereaksi wanger akan menghasilkan endapan cokelat dan jika ditambahkan pereaksi dragendrof menghasilkan endapan merah jingga.

2. Uji saponin

Ditimbang $\quad 0,5 \quad$ gram ekstrak, dimasukkan dalam tabung reaksi, ditambahkan $10 \mathrm{ml}$ air panas dan dikocok selama 10 menit, hingga terbentuk busa atau lebih lalu ditetesi dengan $\mathrm{HCl} 2 \mathrm{~N}$, jika buih tidak hilang dengan penambahan $\mathrm{HCl} 2 \mathrm{~N}$ maka ekstraksi tersebut positif mengandung saponin.

3. Uji tanin

Ekstrak dimasukkan dalam tabung reaksi, ditambahkan $10 \mathrm{ml}$ air panas dan dikocok, lalu ditambahkan $20 \mathrm{ml} \mathrm{NaCl} 10 \%$ dan disaring. Filtrat yang dihasilkan ditambahkan $\mathrm{FeCl3}$ dan apabila terjadi perubahan warna biru tua atau hitam maka positif mengandung tanin.

4. Uji triterpenoid

Sebanyak $5 \mathrm{ml}$ ekstrak dicampur dengan $2 \mathrm{ml}$ kloroform dan $3 \mathrm{ml}$ asam sulfat pekat. Terbentuk warna merah kecoklatan pada antar permukaan menunjukkan adanya triterpenoid.

5. Uji flavonoid Ekstrak ditimbang sebanyak 0,5 gram ditambahkan dengan etanol. Kemudian ditambahkan 5-6 tetes $\mathrm{HCl}$ pekat, membentuk warna merah yang menunjukkan adanya flavonoid dan pembentukan warna orange menandakan adanya senyawa flavon (tiwari et al, 2011).

\section{Uji polifenol}

Larutan ekstrak uji sebanyak $1 \mathrm{ml}$ direaksikan dengan larutan besi (III) klorida 10\%, jika terjadi warna biru tua, biru kehitaman atau hitam kehijauan menunjukkan adanya senyawa polifenol.

\section{Uji kuantitatif}

1. Penentuan total fenolik

Kandungan total fenol dalam ekstrak ditentukan dengan metode Jeong et al. (2004). Dalam sampel ekstrak sebanyak $1 \mathrm{ml}$ ditambahkan dengan $0,2 \mathrm{ml}$ reagen FolinCiocalteu (50\%) dalam tabung reaksi dan kemudian campuran ini divortex selama 3 menit. Setelah interval waktu 3 menit, ditambahkan 0,2 $\mathrm{ml}$ larutan $\mathrm{Na} 2 \mathrm{CO} 3 \quad 7,5 \%$. Selanjutnya campuran disimpan dalam ruang gelap selama 30 menit. Absorbansi ekstrak dibaca dengan spektrofotometer $656 \mathrm{~nm}$. Hasilnya dinyatakan sebagai ekuivalen asam galat dalam mg/kg ekstrak. Kurva kalibrasi dipersiapkan pada cara yang sama menggunakan asam galat sebagai standar.

a. Penentuan Kurva standar asam galat

Sebanyak $50 \mathrm{mg}$ asam galat tambahkan $5 \mathrm{ml}$ etanol 96 $\%$ tambahkan aquadest sampai $100 \mathrm{ml}$. Dari larutan induk dipipet 2, 4, 6, 8, $10 \mathrm{ml}$ dan diencerkan dengan aquadest sampai volume $100 \mathrm{ml}$. sehingga dihasilkan konsentrasi 100, 200, 300, 400, dan $500 \mathrm{mg} / \mathrm{L}$ asam galat. Dari masing-masing konsentrasi diatas dipipet $1 \mathrm{ml}$ ditambah 0,2 ml Reagen Folin Ciocalteu kocok. Diamkan selama 3 menit, tambahkan $0,2 \mathrm{ml}$ larutan $\mathrm{Na} 2 \mathrm{CO} 3$ kemudian kocok hingga homogen. Ukur serapan pada panjang gelombang serapan maksimum $656 \mathrm{~nm}$, lalu buat kurva 
kalibrasinya hubungan antara konsentrasi asam galat dengan absorban.

b. Absorbansi ekstrak

Ditimbang 0,5 gram ekstrak kemudian dilarutkan sampai $50 \mathrm{ml}$ dengan aquades, kemudian ukur larutan sebanyak $1 \mathrm{ml}$, encerkan dengan aquades hingga $10 \mathrm{ml}$. Dari larutan tersebut diambil $1 \mathrm{ml}$ dan ditambahkan 0,2 $\mathrm{ml}$ reagen Folin - Ciocalteu kocok. Diamkan selama 3 menit kemudian tambahkan $0,2 \mathrm{ml}$ $\mathrm{Na} 2 \mathrm{CO} 3 \quad 7,5 \% \quad$ kedalam campuran, diamkan larutan selama 30 menit pada suhu kamar. Ukur serapannya dengan spektrofotometer UVVis pada panjang gelombang serapan maksimum $656 \mathrm{~nm}$ yang akan memberikan komplek biru.

2. Penentuan total flavonoid

Prosedur penentuan kandungan total flavonoid menggunakan metode Meda et al. (2005). $1 \mathrm{ml}$ larutan ekstrak 50\% (b/v) ditambah dengan 0,2 $\mathrm{ml}$ aluminium klorida $10 \%$ yang telah dilarutkan dengan etanol, kemudian divortex dan absorbans dibaca pada $\lambda 440 \mathrm{~nm}$ menggunakan spektrofotometer. Kandungan total flavonoid dinyatakan sebagai ekuivalen kuersetin dalam mg/kg ekstrak. Kurva kalibrasi dipersiapkan dengan cara yang sama kuersetin sebagai standar.

a. Penentuan Kurva Standar Kuersetin

Sebanyak $50 \mathrm{mg}$ kuersetin tambahkan $5 \mathrm{ml}$ etanol $96 \%$ tambahkan aquadest sampai $100 \mathrm{ml}$. Dari larutan induk dipipet 2, 6, 10, 14, $18 \mathrm{ml}$ dan diencerkan dengan aquadest sampai volume $100 \mathrm{ml}$. sehingga dihasilkan konsentrasi 10, 30, 50, 70, dan $90 \mathrm{mg} / \mathrm{L}$ kuersetin. Dari masing-masing konsentrasi diatas dipipet $1 \mathrm{ml}$ ditambah $0,2 \mathrm{ml}$ natrium asetat dan 0,2 $\mathrm{ml} \mathrm{AlCl}_{3}$ kemudian kocok hingga homogen. Ukur serapan pada panjang gelombang serapan maksimum $440 \mathrm{~nm}$, lalu buat kurva kalibrasinya hubungan antara konsentrasi kuersetin dengan absorban.

b. Absorbansi ekstrak

Sebanyak 0,5 g ekstrak dilarutkan dalam labu ukur 50 $\mathrm{ml}$ dengan pelarut etanol hingga tanda. Lalu larutan tersebut dipipet sebanyak $1 \mathrm{ml}$ dilarutkan dalam labu ukur 10 $\mathrm{ml}$ direaksikan dengan $0,2 \mathrm{ml}$ natrium asetat dan $0,2 \mathrm{ml}$ $\mathrm{AlCl}_{3} \quad 10 \%$ kedalam larutan, kemudian didiamkan selama 30 menit. Diukur absorbansi larutan pada panjang gelombang $440 \mathrm{~nm}$ dengan spektrofotometer UV-Vis.

\section{HASIL DAN PEMBAHASAN}

\section{Hasil Penelitian}

Tabel 1. Kandungan Total Senyawa Polifenol

\begin{tabular}{cccc}
\hline Replikasi & Berat sampel $(\mathrm{g})$ & $\% \mathrm{~b} / \mathrm{v}$ & Mg GAE/g ekstrak \\
\hline I & 0,5242 & 3,54325 & 35,4325 \\
II & 0,5342 & 3,47815 & 34,7815 \\
III & 0,5341 & 3,48172 & 34,8172 \\
\hline Rata - rata & & 3,50104 & 35,0104 \\
\hline Standar deviasi & & 0,036598 & 0,365985 \\
\hline
\end{tabular}


Tabel 2. Kandungan Total Senyawa Flavonoid

\begin{tabular}{cccc}
\hline Replikasi & Berat sampel $(\mathrm{g})$ & $\% \mathrm{~b} / \mathrm{v}$ & $\mathrm{Mg}$ QE/g ekstrak \\
\hline I & 0,5242 & 2,10452 & 21,0452 \\
II & 0,5342 & 2,06635 & 20,6635 \\
III & 0,5341 & 2,05759 & 20,5759 \\
\hline Rata - rata & & 2,076153 & 20,76153 \\
\hline Standar deviasi & & 0,024954 & 0,249537 \\
\hline
\end{tabular}

\section{Hasil Ekstraksi}

Simplisia kering kulit pisang raja sebanyak 739,98 g diekstraksi dengan metode maserasi menggunakan pelarut etanol sebanyak 5 liter, didapat ekstrak kental 144,7606 g sehingga diperoleh rendamen 19,562 \%. Sebanyak 20,2191 g ekstrak difraksinasi menggunakan etil asetat dan didapat fraksi etil asetat 0,8299 $\mathrm{g}$ dengan rendamen $4,104 \%$.

Hasil Skrining Fitokimia

Tabel 3. Hasil Skrining Fitokimia ekstrak etil asetat kulit pisang raja

\begin{tabular}{|c|c|c|c|c|}
\hline No & Senyawa kimia & Pereaksi & Hasil & Keterangan \\
\hline 1 & Alkaloid & $\begin{array}{ll}\text { - } & \text { Mayer } \\
\text { - } & \text { Wanger } \\
\text { - } & \text { Dragendrof }\end{array}$ & $\begin{array}{ll}- & \text { Endapan putih } \\
- & \text { Endapan coklat } \\
- & \text { Endapan merah jingga }\end{array}$ & $\begin{array}{l}- \\
-\end{array}$ \\
\hline
\end{tabular}

$\begin{array}{ll}2 & \text { Saponin } \\ 3 & \text { Tannin } \\ 4 & \text { Triterpenoid } \\ 5 & \text { Flavonoid } \\ & \\ 6 & \text { Polifenol }\end{array}$

2 Saponin

3 Tannin

Ditetesi dengan $\mathrm{HCl} 2 \mathrm{~N}$
Penambhan $\mathrm{FeCl}_{3}$
$2 \mathrm{ml}$ kloroform dan $3 \mathrm{ml}$
asam sulfat pekat
Penambahan $\mathrm{HCl}$ pekat
Besi (III) klorida

Buih tidak hilang

Warna biru tua atau hitam

Merah kecoklatan pada antar permukaan

Pembentukan warna merah atau orens

Warna biru tua, biru kehitaman atau hitam kehijauan

Keterangan :

$\begin{array}{ll}(-) & : \text { Tidak terdeteksi } \\ (+) & : \text { Terdeteksi }\end{array}$

\section{Pembahasan}

Ekstraksi kulit pisang raja menggunakan pelc pemanasan dengan tujuan agar senyawasenyawa dapat terekstraksi dengan baik dan tidak mengalami dekomposisi. Etanol dapat merusak dinding sel pada sampel sehingga senyawa yang bersifat polar ataupun non polar dapat terlarut dalam etanol. Selama proses maserasi terjadi proses difusi. Proses ini berlangsung hingga terjadi keseimbangan antara larutan yang ada di dalam sel dan di luar sel. Ketika keseimbangan tercapai masa proses difusi tidak lagi berlangsung (Khopkar, 2008).
Fraksinasi pada ekstrak kulit pisang raja bertujuan untuk memisahkan senyawa berdasarkan kelarutannya terhadap pelarut dengan tingkat kepolaran yang berbeda. Fraksinasi dilakukan dengan pelarut etil asetat. Senyawa polar dan non polar akan terekstrak pada pelarut etil asetat. Hasil fraksinasi ekstrak kasar diperoleh ekstrak etil aseatat $0,8299 \mathrm{~g}$ dengan rendamen 4,104 $\%$.

Uji penapisan fitokimia dilakukan terhadap ekstrak kulit pisang raja menggunakan metode yang dikembangkan oleh Guevera (1985). Penapisan fitokimia yang dilakukan adalah untuk mengetahui adanya kandungan metabolik sekunder yaitu alkaloid, tanin, polifenol, flavonoid, saponin 
dan triterpenoid. Dari hasil penapisan fitokimia menunjukkan bahwa kulit pisang raja mengandung flavonoid, tannin, polifenol, dan triterpenoid tetapi masingmasing ekstrak memiliki kadar yang berbeda-beda yang terlihat secara kualitatif. Dari hasil penapisan fitokimia kulit pisang raja tidak mengandung alkaloid dan saponin. Senyawa fenol diketahui memiliki aktivitas antioksidan. Senyawa fenol merupakan metabolit sekunder yang memainkan peranan dalam pemeliharaan tubuh manusia. Adanya kandungan kimia pada tumbuhan seperti fenol dan flavonoid, mengindikasikan kemungkinan adanya aktivitas antioksidan dan aktivitas antioksidan ini dapat membantu mencegah terjadinya penyakit melalui aktivitas penangkalan radikal bebas (Meenakshi et al., 2012).

Pengujian kandungan senyawa fenolat total merupakan dasar dilakukan pengujian aktivitas antioksidan, karena diketahui bahwa senyawa fenolat berperan dalam mencegah terjadinya peristiwa oksidasi. Fenolat total ekstrak etil asetat kulit pisang raja pada penelitian ini diukur dengan menggunakan prinsip FolinCiocalteau yang didasarkan pada reaksi oksidasi reduksi. Reagen Folin-Ciocalteau digunakan karena senyawa fenolik dapat bereaksi dengan Folin membentuk larutan berwarna yang dapat diukur absorbansinya. Prinsip pengukuran kandungan fenolat dengan reagen Folin-Ciocalteau adalah terbentuknya senyawa kompleks berwarna biru yang dapat diukur pada panjang gelombang $656 \mathrm{~nm}$. Pereaksi ini mengoksidasi fenolat (asam alkali) atau gugus fenolik-hidroksi mereduksi asam heteropoli (fosfomolibdat-fosfotungstat) yang terdapat dapal pereaksi FolinCiocalteau menjadi suatu kompleks momolibdenum-tungsten. Senyawa fenolit bereaksi dengan reagen Folin-Ciocalteau hanya dalam suasan basa agar terjadi disosiasi proton pada senyawa fenolik menjadi ion fenolat. Untuk menciptakan kondisi basa digunakan $\mathrm{Na}_{2} \mathrm{CO}_{3} \quad 7,5 \%$. Warna biru yang terbentuk akan semakin pekat, setara dengan konsentrasi ion fenolat yang terbentuk; artinya semakin besar konsentrasi senyawa fenolik maka semakin banyak ion fenolat yang akan mereduksi asam heteropoli (fosfomolibdat- fosfotungstat) menjadi kompleks momolibdenum-tungsten sehingga warna biru yang dihasilkan semakin pekat (Apsari \& Susanti, 2011). Asam galat digunakan sebagai standar pengukuran dikarenakan asam galat merupakan turunan dari asam hidroksibenzoat yang tergolong asam fenol sederhana. Kandungan fenol asam organik ini bersifat murni dan stabil (Lee et al., 2003).

Kandungan fenolat total dinyatakan dalam GAE (gallic acid equivalent) yaitu jumlah kesetaraan miligram asam galat dalam 1 gram sampel (Lee et al.,2003). Hasil dari penentuan kandungan total senyawa polifenol didapatkan sebesar $3,50104 \% \mathrm{~b} / \mathrm{v}$ atau 35,0104 $\mathrm{mg} \mathrm{GAE} / \mathrm{g}$ ekstrak.

Prinsip penetapan kadar flavonoid adalah adanya reaksi antara flavonoid dengan $\mathrm{AlCl}_{3}$ kompleks berwarna kuning dan dengan penambahan natrium asetat akan membentuk senyawa kompleks berwarna merah muda yang diukur absorbansinya pada panjang gelombang $440 \mathrm{~nm}$ (Rohman et. al, 2009). Kuersetin digunakan sebagai standar pengukuran dikarenakan kuersetin merupakan senyawa flavonoid dari kelompok flavonol (Harborne, 1987).

Kandungan flavonoid total dapat ditentukan secara spektrofotometri dengan reagen $\mathrm{AlCl}_{3}$ dan dinyatakan dalam QE (quersetin equivalent) yaitu jumlah kesetaraan miligram quersetin dalam 1 gram sampel. Kadar kandungan total flavonoid ekstrak etil asetat kulit pisang raja yaitu sebesar 2,076153\% b/v atau $20,76153 \mathrm{mg}$ QE/g ekstrak.

Pada penelitian sebelumnya yang dilakukan oleh Edi suryanto, 2011 tentang potensi senyawa polifenol antioksidan dari pisang goroho (Musa sapiens sp.) menunjukkan bahwa hasil analisis dari ekstrak etanol memiliki kandungan total fenolik sebesar 152,14 $\mathrm{mg} / \mathrm{g}$ sampel, sedangkan kandungan total flavonoid sebesar 4,75 mg/g sampel.

Pada penelitian yang dilakukan oleh Asmiah, 2017 tentang kandungan total polifenol dan flavonoid ekstrak etanol kulit pisang ambon memiliki kandungan total fenolik sebesar 3,28660\% b/v atau 32,8660 mg GAE/g ekstrak, sedangkan kandungan total flavonoid sebesar $13,15136 \% \mathrm{~b} / \mathrm{v}$ atau $131,5136 \mathrm{mg} \mathrm{QE} / \mathrm{g}$ ekstrak. 
Perbandingan hasil penelitian total polifenol dan flavonoid pada kulit pisang raja dan kulit pisang ambon cukup signifikan yang terlihat pada total flavonoid kulit raja yaitu $2,076153 \% \mathrm{~b} / \mathrm{v}$ atau 20,76153 mg QE/g ekstrak sedangkan total flavonoid pada kulit pisang ambon sebesar $13,15136 \% \mathrm{~b} / \mathrm{v}$ atau $131,5136 \mathrm{mg} \mathrm{QE} / \mathrm{g}$ ekstrak.

Tinggi rendahnya kandungan fenolik total dalam ekstrak kulit pisang berhubungan dengan aktivitas penangkal radikal bebas dari pelarut yang digunakan. Kemampuan aktivitas penangkal radikal bebas ekstrak kulit pisang disebabkan oleh adanya senyawa-senyawa kimia yang dapat berperan sebagai penagkal radikal bebas. Flavonoid mampu menghambat reaksi oksidasi melalui mekanisme penagkal radikal bebas. Flavonoid dengan gugus hidroksil akan berfungsi sebagai penangkal radikal bebas dan semakin banyak gugus hidroksil akan meningkatkan aktivitas sebagai antioksidan (Rohman, 2005).

\section{PENUTUP}

\section{Kesimpulan}

Berdasarkan hasil penelitian yang telah dilakukan, maka dapat disimpulkan bahwa kandungan total fenolik dengan menggunakan reagen Folin-Ciocalteu sebesar 3,50104\% b/v atau 35,0104 mg GAE/g ekstrak, sedangkan kandungan total flavonoid dengan menggunakan reagen $\mathrm{AlCl}_{3}$ sebesar 2,076153\% b/v atau 20,76153 mg QE/g ekstrak.

\section{Saran}

Saran yang dapat diberikan untuk penelitian selanjutnya adalah perlu dilakukan penelitian lebih lanjut terhadap kandungan total polifenol dan flavonoid dengan menggunakan pelarut lainnya dengan lebih teliti.

\section{DAFTAR PUSTAKA}

Badan Pusat Statistik Republik Indonesia. (2013). Produksi Buah-buahan Menurut Profinsi. [online]. Tersedia:[17 Desember 2014].

Chabuck, Z. (2013). “Antimicrobial Effect Of Aqueous Banana Extract". Research Gate. 27, 73-75.
Deptan.(2005). Prospek dan Arah Pengembangan Agribisnis Pisang. [online].

Tersedia:http://www.deptan.go.id. [30 Maret 2007].

Edi suryanto. (2011). "Potensi Senyawa Polifenol Antioksidan dari Pisang Goroho

(Musa sapien sp.)".Prosiding Teknologi dan Kesehatan Seminar Nasional Penelitian dan PKM: Sains,.4, 31.

Fitrianingsih, S. P. (2012). "Uji Efek HipoglikemiaEkstrak Kulit Buah Pisang Raja (Musa paradisiaca var. sapientum)".Prosiding Seminar Nasional Penelitian dan PKM: Sains, Teknologi dan Kesehatan. 3, (1), 73-80.

Harbone.(1987). Penumtun Cara Modern Menganalisis Tumbuhan. Bandung: Institut Teknologi Bandung.

Jeong, S. M. (2004). "Effect Of Heat Treatment On The Antioxidant Activity Of Extract From Peels". Journal Of Agricultural and Food Chemistry. 52, 3389-3393.

Lee et.al. (2003). "Cocoa Has More Phenolic Phytochemical and A Higher Antioxidant Capacity than Teas and Red Wine".Journal Agric. Food Chem. 51,7292-7295.

Meda, A. L. (2005). "Detemination Of The Total Phenolic, Flavonoid, and Proline Content In Burkina Fasan Money". Food Chemistry. 91, 571577.

Meenakshi et.al. (2012). "Skrining Fitokimia dan Analisis Kromatografi Lapis Tipis Komponen Kimia”. Journal Biofarmasi. 3, 26-31.

Pane, Elpira Rosa. (2013). “Uji Aktivitas Senyawa Antioksidan dari Ekstrak Metanol Kulit Pisang Raja (Musa paradisiaca var. sapientum)". Valensi. 3, (2), 1978-8193. 